\title{
Soluble M3 proteins of murine gammaherpesviruses 68 and 72 expressed in Escherichia coli: analysis of chemokine-binding properties
}

\author{
R. MATÚŠKOVÁ, P. PANČÍK, I. ŠTIBRÁNIOVÁ, P. BELVONČÍKOVÁ, I. REŽUCHOVÁ, M. KÚDELOVÁ*
}

\author{
Institute of Virology, Slovak Academy of Sciences, Dúbravská cesta 9, 84505 Bratislava, Slovak Republic
}

Received September 10, 2015; accepted September 11, 2015

\begin{abstract}
Summary. - M3 protein of murine gammaherpesvirus 68 (MHV-68) was identified as a viral chemokinebinding protein 3 (vCKBP-3) capable to bind a broad spectrum of chemokines and their receptors. During both acute and latent infection MHV-68 M3 protein provides a selective advantage for the virus by inhibiting the antiviral and inflammatory response. A unique mutation Asp307Gly was identified in the M3 protein of murine gammaherpesvirus 72 (MHV-72), localized near chemokine-binding domain. Study on chemokine-binding properties of MHV-72 M3 protein purified from medium of infected cells implied reduced binding to some chemokines when compared to MHV-68 M3 protein. It was suggested that the mutation in the M3 protein might be involved in the attenuation of immune response to infection with MHV-72. Recently, Escherichia coli cells were used to prepare native recombinant M3 proteins of murine gammaherpesviruses 68 and 72 (Pančík et al., 2013). In this study, we assessed the chemokine-binding properties of three M3 proteins prepared in E. coli Rosetta-gami 2 (DE3) cells, the full length M3 protein of both MHV-68 and MHV-72 and MHV-68 M3 protein truncated in the signal sequence (the first $24 \mathrm{aa}$ ). They all displayed binding activity to human chemokines CCL5 (RANTES), CXCL8 (IL-8), and CCL3 (MIP-1 $\alpha$ ). The truncated MHV-68 M3 protein had more than twenty times reduced binding activity to CCL5, but only about five and three times reduced binding to CXCL8 and CCL3 when compared to its full length counterpart. Binding of the full length MHV-72 M3 protein to all chemokines was reduced when compared to MHV-68 M3 protein. Its binding to CCL5 and CCL3 was reduced over ten and seven times. However, its binding to CXCL8 was only slightly reduced (64.8 vs 91.8\%). These data implied the significance of the signal sequence and also of a single mutation (at aa 307) for efficient M3 protein binding to some chemokines.
\end{abstract}

Keywords: murine gammaherpesvirus; chemokine-binding protein; M3 protein, signal sequence

\section{Introduction}

Herpesviruses and poxviruses encode viral protein homologs of chemokines, members of a complex family of cytokines that control the recruitment of cells to

*Corresponding author. E-mail: virukude@savba.sk; phone: +4212-59302-434

Abbreviations: GAGs = glycoaminoglycans; MHV-68 = murine gammaherpesvirus 68; MHV-72 = murine gammaherpesvirus 72; $\mathrm{vCKBP}=$ viral chemokine-binding protein; $\mathrm{vCKR}=$ viral homolog of the chemokine receptor the sites of infection and inflammation. They also contain viral homologs of chemokine receptors (vCKRs) and viral chemokine-binding proteins (vCKBPs) (Lalani et al., 2000). A large number of herpesvirus-encoded CKRs with sequence similarity to cellular CKRs have been identified and characterized. Only two of these homologs have been identified in the poxviruses swinepox and capripox, but no functional data are available up to date. In contrast to herpesviruses, poxviruses are known to encode soluble vCKBPs that are secreted in large amounts from infected cells and bind chemokines in solution. Chemokines play a crucial role in host defense. They are involved in both innate and adaptive immunity (Luster, 2002), and thus many infectious agents have 
developed strategies to manipulate the host chemokine network. Chemokines are classified into four subfamilies based on the arrangement of cysteine residues at their $\mathrm{N}$-terminus: CXC, CC, C, and CX3C (Zlotnik and Yoshie, 2000). The specific effects of chemokines on target cells are mediated by the members of a family of seven-transmembrane-spanning G-protein coupled receptors. As predominantly basic, positively charged molecules, chemokines also interact with the negatively charged glycosaminoglycans (GAGs) expressed on the endothelial cell surface (Proudfoot et al., 2003).

Recently, a soluble vCKBP was identified, designated as M3 protein, hvCKBP or vCKBP-3 encoded by murine gammaherpesvirus 68 (MHV-68), with no sequence similarity to cellular chemokine-binding receptors and cytokine binding protein II (vCKBPII) encoded by poxvirus (Carfi et al. 1999, van Berkel et al., 2000). This protein $\left(\mathrm{M}_{\mathrm{r}}=44 \mathrm{kDa}\right)$ is secreted from infected cells in large amounts, binds chemokines of the four subfamilies (CC, CXC, $\mathrm{C}$ and $\mathrm{CX}_{3} \mathrm{C}$ ) with high affinity and blocks their interaction with CKRs. This is unusual because cellular CKRs display binding specificity and the poxvirus vCKBP-II is specific for CC chemokines. M3 protein prevents chemokine-induced signal transduction in vitro (Parry et al., 2000; van Berkel et al., 2000) and it also blocks the induction of intracellular signaling. It has also been shown to block the interactions of chemokines with GAGs (Webb et al., 2003). MHV-68 is a natural pathogen of murid rodents belonging to the species Murid herpesvirus 4 (MuHV-4) (the genus Rhadinovirus, the subfamily Gammaherpesvirinae) (van Regenmortel et al., 2000). It is genetically related to the primate gammaherpesviruses - Saimiriine herpesvirus 2, Human herpesvirus 8, and Human herpesvirus 4 (Virgin et al., 1997). These viruses are able to establish latent, life-long infections and are often associated with various types of malignancies, such as Kaposi's sarcoma and B-cell lymphomas (Sunil-Chandra et al., 1992; Kúdelová and Rajčáni, 2009). MHV-68 is intensively studied in many laboratories since it is an attractive experimental model for gammaherpesvirus infection (Rajčáni and Kúdelová, 2007).

MHV-68 M3 protein, encoded by early-late lytic gene, is expressed continually during lytic infection, during the establishment of latent infection, and during latency in vivo (Simas et al., 1999; Ebrahimi et al., 2003). M3 protein is predicted to play a role in the establishment of latency by indirect protection of latently infected B cells during lytic infection of macrophages and dendritic cells (Flaño et al., 2000; Marques et al., 2003). M3 protein produced by cells infected with MHV-68 may alter the migration of CCR7expressing T, B, or dendritic cells towards local gradients of CCL19 and CCL21, thus potentially delaying the initiation of a specific immune response against the virus (Jensen et al., 2003). M3 protein may also significantly inhibit the chemokine effector functions, thereby inhibiting the antiviral activity of recruited leukocytes and thus allowing the virus to replicate at higher levels in the presence of cells serving as potential targets for the establishment of latency (Sarawar et al., 2002). In support of this, upregulation of lymphocyte trafficking and the control of macrophage trafficking in the CNS during MHV-68 infection has been demonstrated (van Berkel et al., 2002). The host response to viral infection with M3 del mutant MHV-68 was shown altered in both the lungs and the germinal reaction center in the spleen, suggesting M3 gene to be responsible for host-specific differences (Hughes et al., 2011). Alexander et al. (2002) first reported the crystal structure model of M3 protein bound to the CC chemokine CCL2 (monocyte chemoattractant protein 1) and described the binding sites of this $\mathrm{VCKBP}$ recognized by the chemokine and also by the cellular receptor CCR2.

In addition to the MHV-68 virus, the only virus classified as a MuHV-4 species to date, murine gammaherpesvirus 72 (MHV-72) (clone h3.7) is very likely a strain of murine gammaherpesvirus. Its biological properties related to MHV-68 have also been characterized (Mistríková et al., 2000; Rašlová et al., 2001) and the differences in genome sequence encompassing 19 genes $(22,899$ bp) have been identified (Mačáková et al., 2003; Valovičová et al., 2006; Belvončíková et al., 2008; Halásová et al., 2011). MHV-72 appears to be less pathogenic and more oncogenic than MHV-68 (Nash et al., 2001), displaying delayed cytopathic effect in infected normal murine mammary gland cells (up to 48 hours) and higher malignancy development rate in long-term infected mice in comparison with MHV-68 (Mistríková et al., 2000). Besides MHV-72, several other murine herpesviruses were found occurring throughout some mouse species, which display similar pathogenesis of acute and latent infection manifested in their hosts. Among these is the Wood mouse herpesvirus isolated from wood mouse in the UK, the full genome sequence of which was recently identified by Hughes et al. (2010). Biological properties of some other murine herpesviruses (MHV-60, MHV-78, MHV-76, MHV-Šumava, MHV-4556) isolated from bank vole and wood mice in Slovakia and Bohemia (Blaškovič et al., 1980; Kožuch et al., 1993; Blaškovičová et al., 2007; Halásová et al., 2011; Kúdelová et al., 2012) are also studied (reviewed by Wagnerová et al., 2015).

In a previous study, we showed that M3 gene of MHV-72 has codon-changing mutation at nucleotide position 920 (Asp307Gly) located near the chemokine-binding domain (Belvončíková et al., 2008). This mutation was suggested to be involved in attenuating the immune response to MHV-72 infection. A study of the binding affinities of the MHV-72 M3 protein purified from the media of infected BHK-21 cells to five human chemokines (CCL3, CCL5, CCL11, CCL2, and CXCL8) showed that MHV-72 M3 protein exhibited significantly lower binding affinity to CCL5 and CXCL8 (only $11.1 \%$ and $20 \%$ ) than MHV-68 M3 protein, but had comparable affinity to CCL11, CCL2, and CCL3. On the other hand, the amount of MHV-72 M3 protein bound to 
both human CCL11 and CCL2 reached about $90 \%$ of that detected for MHV-68 M3 protein. In our first study, we prepared recombinant His-tagged M3 proteins of MHV-68 and MHV-72 using the pET-26b(+) expression system. We optimized the expression of M3 proteins of MHV-68 and MHV-72 in E. coli BL21 (DE3) and Rosetta (DE3) cells as well as their purification by Ni-NTA chromatography under both denaturing and native conditions (Pančík et al., 2013).

In this study, we determined chemokine-binding affinities of three recombinant M3 proteins: two of MHV-68 (the full length or truncated in the signal sequence) and the full length MHV-72, prepared in E. coli Rosetta-gami 2 (DE3) cells, to human chemokines CCL5, CXCL8, and CCL3. We described the changes in these properties of M3 protein caused by the absence of signal sequence and the presence of Asp307Gly mutation in this protein, which is unique for the MHV-72.

\section{Materials and Methods}

Cells. Normal murine mammary gland (NMuMG) (ATCC CRL1636) and Baby hamster kidney 21 (BHK-21) fibroblasts (ATCC CCL-10) cell lines were maintained in DMEM (GIBCO) supplemented with 10\% (v/v) FCS, 2 mmol/l glutamine (Invitrogen) and penicillin-streptomycin-amphotericin $(100 \mathrm{mg} / \mathrm{ml})$ (Cambrex) at $37^{\circ}$ C. E. coli Rosetta-gami2 (DE3) cells were obtained from Novagen. E. coli JM109 cells were obtained from Promega.

Viruses. Two murine gammaherpesviruses (MHV-68 and MHV-72) originally isolated from the bank vole, Myodes glareolus (Blaškovič et al., 1980), kindly provided by Prof. Mistríková (Faculty of Natural Sciences, Comenius University, Bratislava, Slovakia) were plaque purified twice to obtain clones f2.6 (MHV-68) and h3.7 (MHV-72) (Kúdelová et al., 2012). Viral DNA was isolated and purified from virions as previously described (Rašlová et al., 2000).

Recombinant expression plasmids with the full length $M 3$ genes of $M H V-68$ and $M H V-72$. Two expression plasmids (P26-M3his/68 and P26-M3his/72) containing the full length ORF M3 of MHV-68 or MHV-72 with 6 triplets encoding histidines at the C-terminal end described previously by Pančík et al. (2013) were used.

PCR amplification of truncated $M 3$ gene of $M H V-68$. To amplify the genomic region corresponding to ORF M3 of MHV-68 (Acc. No. AF105037) shortened by triplets of the first 24 (aa), recombinant plasmid pGEM-TM3 MHV-68 prepared previously by Belvončíková et al. (2008) was used as a template. Primers derived from the MHV-68 M3 sequence (Virgin et al., 1997) flanked by NdeI and XhoI sites (bold, underlined) and 6 triplets encoding histidines (in italic) at 5'end (5'-ACA TAT GCA CCA TCA TCA TCA TCA TCT TAC TCT AGG TTT GGC ACC TGC T-3' and 5'-ACT CGA GTC TAC TAC TAA TGA TCC CCA AAA TAC TCC AGC CT-3') were used in PCR to amplify desired sequence as previously described Pančík et al. (2013).

Cloning and sequencing of truncated MHV-68 M3 gene. The PCR product containing truncated ORF $\triangle \mathrm{ssM} 3$ of MHV-68
(1 $188 \mathrm{bp}$ ) was further purified and cloned into expression plasmid pET-26b(+) (Novagen) according to Pančík et al. (2013). A novel recombinant plasmid $\mathrm{P} 26-\Delta$ ssM3his/68 was sequenced using a commercial sequencing service (BITCET, Faculty of Natural Sciences, Comenius University, Bratislava, Slovakia), which confirmed the correct ORF of cloned insert. For sequencing, the two universal primers T7F (20-mer) and T7R (19-mer) were used.

Expression of M3 proteins. Competent E. coli Rosetta-gami2 (DE3) cells were transformed with expression plasmids P26M3his/68, P26- $\Delta$ ssM3his/68, and P26-M3his/72. Single colonies were picked and inoculated into $10 \mathrm{ml}$ of LB medium (SigmaAldrich) containing $30 \mu \mathrm{g} / \mathrm{ml}$ kanamycin (Bioline), $34 \mu \mathrm{g} / \mathrm{ml}$ chloramphenicol and $12.5 \mu \mathrm{g} / \mathrm{ml}$ tetracycline (Sigma-Aldrich) grown at $37^{\circ} \mathrm{C}$ overnight to make a starter culture. For further purification, cells were inoculated into 11 of Terrific Broth media (1.2\% (w/v) peptone, $2.4 \%(\mathrm{w} / \mathrm{v})$ yeast extract, $72 \mathrm{mmol} / \mathrm{K}_{2} \mathrm{HPO}_{4}, 17 \mathrm{mmol} / \mathrm{l}$ $\mathrm{KH}_{2} \mathrm{PO}_{4}, 0.4 \%(\mathrm{w} / \mathrm{v})$ glycerol) with antibiotics as above. Cells were grown to $\mathrm{OD}_{600}=0.6$. The expression of $\mathrm{M} 3$ protein was induced by adding IPTG to a final concentration of $0.5 \mathrm{mmol} / \mathrm{l}$ and the protein was produced at $37^{\circ} \mathrm{C}$ for $2 \mathrm{hr}$. E. coli cells were harvested by centrifugation at $6,000 \mathrm{xg}$ at $4^{\circ} \mathrm{C}$ for $10 \mathrm{~min}$, washed with $2 \mathrm{ml}$ PBS, centrifuged at $6,000 \mathrm{x}$ gagain, and stored at $-80^{\circ} \mathrm{C}$. To check the expression of M3 protein, aliquots of $E$. coli cells were collected by centrifugation (8,000 x g for $3 \mathrm{~min}$ ), resuspended in loading buffer and analyzed by SDS PAGE on $12.5 \%$ gel (Laemmli, 1970).

Purification of M3 proteins. The recombinant MHV-68 M3, MHV-68 $\triangle \mathrm{ssM} 3$, and MHV-72 M3 proteins with $6 \times$ His-tag on their C- or Ntermini designated as $\mathrm{M} 368 \mathrm{HC}, \Delta \mathrm{ssM} 368 \mathrm{HN}$, and M372HC, respectively, were purified under native conditions using Ni-NTA agarose (Qiagen) according to the manufacturer's instructions with minor modifications. Before purification, the cells were weighted. $1 \mathrm{~g}$ of wet cells was resuspended in $20 \mathrm{ml}$ of lysis buffer $\left(50 \mathrm{mmol} / 1 \mathrm{NaH}_{2} \mathrm{PO}_{4}\right.$, $300 \mathrm{mmol} / \mathrm{l} \mathrm{NaCl}, 10 \mathrm{mmol} / \mathrm{l}$ imidazole, $10 \%$ (w/v) glycerol, $0.2 \%$ (w/v) sulfobetaine-14) (SB-14, Sigma-Aldrich), $1 \mathrm{mg} / \mathrm{ml}$ lysozyme, protease Inhibitor Cocktail Set III, EDTA-Free (Calbiochem) (added at a dilution 1:200 to buffer to prevent undesired protein degradation) and incubated at $4^{\circ} \mathrm{C}$ for $30 \mathrm{~min}$. Cells in the suspension were disrupted by French Press Cell Disruptor (Thermo Scientific) with two rounds at $20000 \mathrm{psi}$. The cell lysis mixture was then treated with 25 U Benzonase ${ }^{\star}$ Nuclease (Qiagen) for $10 \mathrm{~min}$ to remove nucleic acids followed by centrifugation at $18,500 \mathrm{xg}$ at $4^{\circ} \mathrm{C}$ for $30 \mathrm{~min}$. The supernatant was loaded onto a chromatography column with $\approx 0.6$ $\mathrm{ml}$ of Ni-NTA agarose resin. After a short incubation at $4^{\circ} \mathrm{C}$, nonspecifically bound proteins were washed away using four rinses with $1 \mathrm{ml}$ of lysis buffer without $25 \mathrm{mmol} / \mathrm{l}$ imidazole. Finally, each M3 protein was eluted from the column with the same buffer containing $250 \mathrm{mmol} / \mathrm{l}$ imidazole into three fractions. Each fraction was analyzed on $12.5 \%$ SDS-PAGE and stained using Coomassie Brilliant Blue R-250 (Santa Cruz) and the amount of the protein measured using Qubit 3.0 Fluorometer (Life Technologies).

Western blot analysis. Purified samples of M368HC, $\Delta$ ssM368HN, $\mathrm{M} 372 \mathrm{HC}$ proteins were separated on $12.5 \%$ SDS-PAGE and then identified using His-Tag ${ }^{\circledR}$ Monoclonal Antibody (Novagen) diluted 
Table 1. Characteristics and chemokine-binding activities of recombinant M3 proteins prepared in $E$. coli

\begin{tabular}{lcccc}
\hline $\begin{array}{l}\text { Name of recombinant } \\
\text { protein }\end{array}$ & Protein length (aa) & $\begin{array}{c}\text { His-tag anchor } \\
\text { localization at protein } \\
\text { terminal end }\end{array}$ & CCL5 & Binding activity to chemokine (\%) \\
\cline { 3 - 5 } M368HC & 406 & $\mathrm{C}$ & $2.1^{\mathrm{d}=1: 100}$ & $21.2^{\mathrm{d}=1: 5}$ \\
\hline$\Delta$ ssM368HN & 382 & $\mathrm{~N}$ & $88.3^{\mathrm{d}=1: 5}$ & 90 \\
\hline M372HC & 406 & $\mathrm{C}$ & $95.6^{\mathrm{d}=1: 5}$ & 67.6 \\
\hline
\end{tabular}

$\mathrm{d}=1: 100$ - sample diluted 100 times, ${ }^{\mathrm{d}=1: 5}$ - sample diluted 5 times.

in 2,5\% (w/v) BSA in TBST buffer at the ratio 1:1000. The incubation was performed overnight at $4^{\circ} \mathrm{C}$. Unbound antibody was washed away with TBST buffer three times for $15 \mathrm{~min}$. Anti-mouse IgG HRP conjugate (Promega) diluted in TBST buffer at the ratio 1:2,500 was bound $1 \mathrm{hr}$ at room temperature and then washed away as described earlier (Pančík et al., 2013). Proteins on the PVDF membrane were visualized by staining with the chemiluminescent dye SuperSignal West Dura extended duration substrate (Pierce) and photographed using a Kodak Image Station 2000MM.

Determination of chemokine-binding activities of recombinant M3 proteins. Anti-cytokine activities were detected for $200 \mathrm{ng}$ recombinant M3 protein (20 ng /ul) and its aliquots diluted at ratios 1:5, 1:10, 1:50, and 1:100. Recombinant M3 protein was screened for affinity to human chemokines - CCL5 (RANTES), (CXCL8 (IL-8) CCL3 (MIP-1 $\alpha$ ), activities, using ELISA kits: Human CCL5/RANTES DuoSet (DY278, UK), CXCL8/IL-8 (Bender MedSystems, Austria), and Human CCL3/ MIP-1 alpha DuoSet (DY270, MN, USA). For each assay, $50 \mathrm{pg}$ of the recombinant cytokine in ELISA diluent (PBS supplemented with $1 \%$ BSA) were mixed with $10 \mu$ of recombinant protein $\mathrm{M} 3$, undiluted or diluted, and/or PBS as a negative control, to give a total volume of $100 \mu \mathrm{l}$. Each mixture was incubated for $1.5 \mathrm{~h}$ at room temperature, with gentle shaking and then applied to the ELISA plates $(100 \mu \mathrm{l} /$ well). Duplicate assays were performed for each cytokine and each sample was measured in duplicate per assay. A reduction in detectable levels of a particular cytokine, when compared with $50 \mathrm{pg}$ of commercial recombinant cytokine as a control, was interpreted as an evidence of cytokine-binding activity of the sample. The results, expressed as mean +/-SEM of two independent experiments, constitute percentage reduction of OD reading compared with the control.

\section{Results}

Construction of bacterial expression vector with truncated M3 gene of MHV-68

The sequence of MHV-68 M3 ORF lacking the first 72 nts (24 aa) ( $\Delta$ ssM3) was amplified using pGEMT-M3 MHV-68 previously prepared by Belvončíková et al. (2008) as a template, and primers containing NdeI and XhoI linker sequences. The forward primer included a sequence encoding six histidines at its 5 '-end, allowing the expressed protein to be purified by affinity chromatography. This PCR product was cloned into a pET-26b(+) vector via the NdeI and XhoI restriction sites creating recombinant plasmid $\mathrm{P} 26-\Delta \mathrm{ssM} 3 \mathrm{his} / 68$. The presence of desired sequence in the plasmid P26- $\Delta$ ssM3his/68 was verified using a commercial sequencing service.

\section{Expression of recombinant M3 proteins in E. coli}

The cells of E. coli Rosetta-gami 2 (DE3) strain were transformed with a recombinant bacterial expression vector (P26-M3his/68, P26- $\Delta$ ssM3his/68P26 or M3his/72) according to Pančík et al. (2013). Expression of each of the proteins M368HC, $\triangle$ ssM368HN or M372HC (Table.1) was induced with $0.5 \mathrm{mmol} / \mathrm{l}$ IPTG and evaluated by SDS-PAGE. We confirmed that M3 proteins of the expected size $(\sim 44 \mathrm{kDa})$ could be found in the lysates of transformed cells including truncated MHV-68 M3 protein (Fig.1, lane 3). The amount of all M3 proteins expressed was comparable with M3 proteins prepared by Pančík et al. (2013) in E. coli BL21 (DE3) or Rosetta (DE3) cells strains (data not shown).

Purification of recombinant M3 protein by Ni-NTA chromatography

To purify M368HC, $\Delta$ ssM368HN or M372HC proteins under native conditions, we used purification conditions optimized by Pančík et al. (2013). All recombinant M3 proteins were detected by SDS PAGE and Western blot analysis using

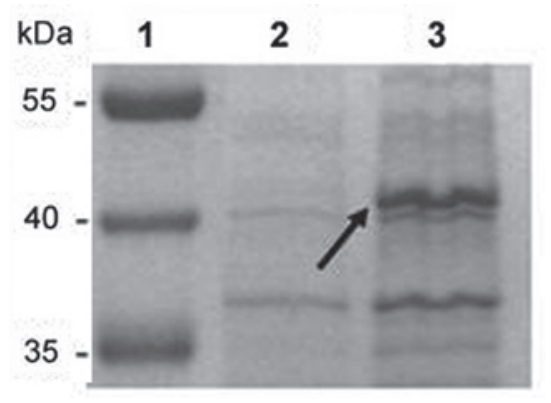

Fig. 1

Expression of truncated M3 protein of MHV-68 in E. coli SDS-PAGE of E. coli Rosetta-gami2 (DE3) cell-lysate, $2 \mathrm{hr}$ after IPTG induction at $37^{\circ} \mathrm{C}$. PageRuler Prestained Protein Ladder (lane 1), cells transformed with P26- $\Delta$ ssM3his/68, uninduced (lane 2) and induced (lane 3). The arrow indicates the $42.4 \mathrm{kDa}$ truncated $\mathrm{M} 3$ protein. 


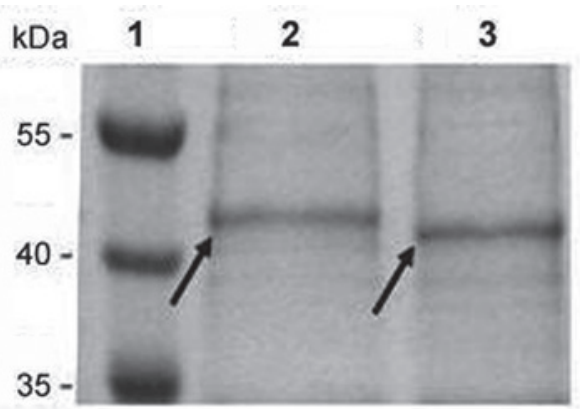

Fig. 2

Purification of native recombinant MHV-68 M3 proteins by Ni-NTA chromatography

SDS-PAGE of M3 proteins expressed in E. coli, strain Rosetta-gami 2 (DE3), and purified by affinity chromatography. PageRuler Protein Prestained Ladder (lane 1), the full-length $\mathrm{M} 368 \mathrm{HC}$ protein (lane 2) $(44.8 \mathrm{kDa})$ and truncated $\Delta s s M 368 \mathrm{HN}$ protein (lane 3) $(42.4 \mathrm{kD})$. The arrows indicate M3 proteins. a His-Tag ${ }^{\oplus}$ monoclonal antibody (data not shown), which confirmed that we obtained all recombinant M3 proteins in quality and amount allowing analyses of their biological properties. As shown in Fig. 2, the full length and truncated M3 protein of MHV-68 exhibited different mobility in SDS PAGE (lanes 2 and 3).

Analysis of chemokine-binding activity of recombinant M3 proteins

The ELISA assay of the chemokine-binding properties of the full length of MHV-68, the MHV-68 M3 truncated by the signal sequence and the full length MHV-72 M3 protein showed that they all were able to bind each of the chemokines (CCL5, CXCL8, and CCL3) tested (Table 1; Fig. 3). The strongest affinity displayed the full length MHV-68 M3 protein to CCL5, when as few as 2 ng of protein bound this

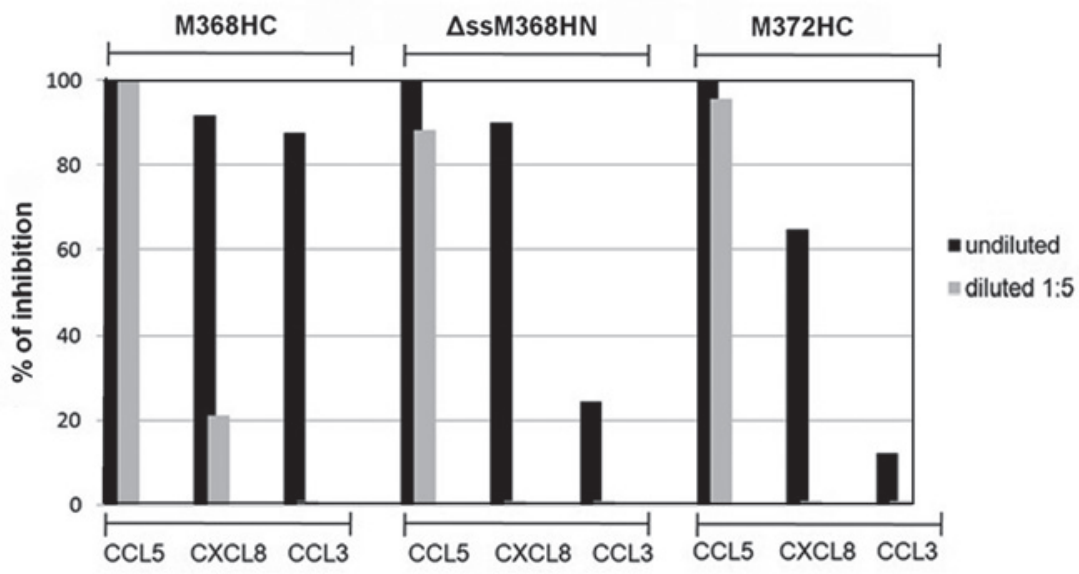

Fig. 3

Binding activity of the full-length (M368HC, M372HC) and truncated ( $\triangle$ ssM368HN) recombinant M3 proteins to CCL5, CXCL8, and CCL3 chemokine

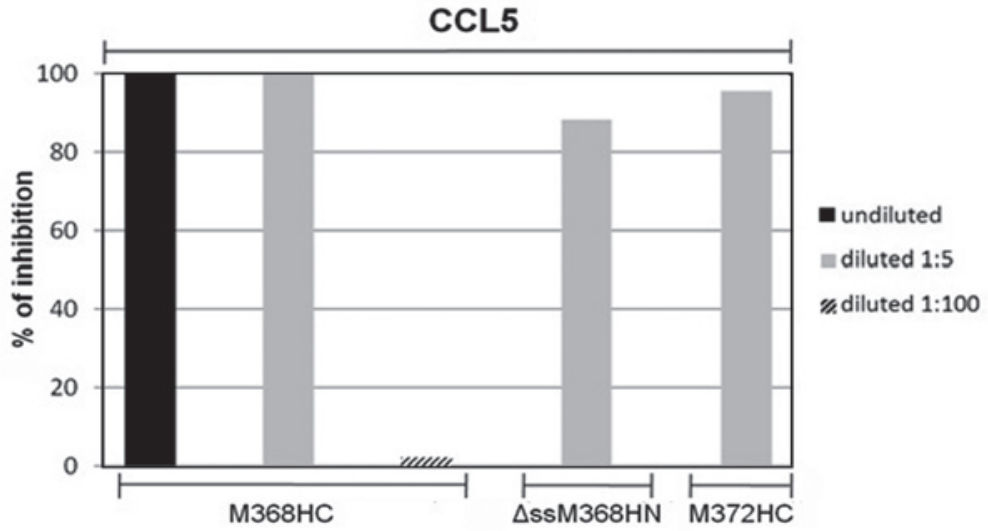

Fig. 4

Comparison of binding activities of the full-length $(\mathrm{M} 368 \mathrm{HC}, \mathrm{M} 372 \mathrm{HC})$ and truncated $(\Delta \mathrm{ssM} 368 \mathrm{HN})$ recombinant M3 proteins to CCL5 chemokine. 
cytokine (Table 1; Fig. 4). In comparison to the full length MHV-68 M3 protein, truncated MHV-68 M3 protein had significantly, more than twenty times, reduced binding activity to CCL5. The truncation of MHV-68 M3 protein caused only about five and three times reduced activity to CXCL8 and CCL3, when compared to its full length counterpart. It should be noted that both proteins, five times diluted and undiluted, displayed binding activity to CXCL8 and CCL3 (Table 1). The full length MHV-72 M3 protein as compared to MHV-68 M3 had only slightly reduced binding to CXCL8 (64.8 vs 91.8\%), but about seven times reduced binding to CCL3 (12.3 vs 87.6\%). Binding of five times diluted full length MHV-72 M3 protein to CCL5 was comparable with that of MHV-68.

\section{Discussion}

Gammaherpesviruses are predominantly host-specific, so the virus $v s$ host immune system interaction plays a crucial role in the viral infection, particularly in the latency establishment and reactivation from latency (Speck and Ganem, 2010). It is very important for the proper function of the host immune system to effectively deliver the immunocompetent cells to the site of virus replication. Small soluble peptides of cytokine family, known as chemokines, are ligands that trigger many signaling cascades involved in innate immunity via binding to their receptors on surface of the immunocompetent cells (Luster, 2002; Proudfoot et al., 2003). Many viruses developed strategies to overcome this signal transduction, which implies its significant role in the battle against viral infections (Alcami et al., 2003). There are several pathogenic manifestations murid and human gammaherpesviruses have in common, which is the consequence of the genome homology. However, genome of murid herpesvirus 4 (MuHV-4) possesses some unique genes without known sequence homology to other viral or human genes. Out of these, M3 gene of MuHV-4 coding for the $\mathrm{M} 3$ protein (vCKBP of murine gammaherpesvirus) was the point of interest of last decade, pioneered by the work of Alexander et al. (2002). They used a recombinant baculovirus infecting insect cells Sf9 to produce enough M3 protein to determine the crystal structure of M3 both alone and bound to CC chemokine CCL2. M3 protein is a unique viral decoy receptor, which binds a broad spectrum of chemokines, thus destabilises chemokine network in vitro and in vivo (Parry et al., 2000; van Berkel et al., 2000; Jensen et al., 2003). In spite of the high expression in lungs and spleen of experimentally infected laboratory mice (Mus musculus), its significant benefit for the virus replication or pathogenicity has not been successfully proved (Bridgeman et al., 2001). This could imply stronger interplay of the virus replication on the immunity of its natural host (Apodemus spp. or Myo- des spp.), which ought not to be fully compatible with the immune system of laboratory mice (Hughes et al., 2011). The study of M3 protein alone could, however, be beneficial for human medicine. Because of its strong and specific binding of chemokines of all four subfamilies (Parry et al., 2000; Belvončíková et al., 2008), it can serve as a potential therapeutic tool for treating diseases linked to the deregulation of chemokine network, such as diabetes mellitus type I (Martin et al., 2007, 2008; Lira et al., 2009). A number of other autoimmune diseases leading to chronic inflammation could be treated with chemokine antagonists (Proudfoot et al., 2003; Pyo et al., 2004; Wu et al., 2008).

All experiments mentioned above refer to M3 protein of MHV-68. However, data of the binding affinity to individual chemokine are still rare. In our previous study on MHV-72 (clone h3.7), Belvončíková et al. (2008) identified that M3 protein of MHV-72 differed from its MHV-68 counterpart in only a single amino acid mutation, which is located near the chemokine-binding domain. They found that MHV-72 M3 protein released into the media of infected BHK-21 cells bound only $11 \%$ and $20 \%$ of the amount of CCL5 and CXCL8 bound by MHV-68 M3 protein purified by the same manner. In a following study, Pančík et al. (2013) prepared a novel suitable expression system for production of recombinant M3 proteins in E. coli cells, allowing their chemokine-binding properties to be studied. The properties of M3 protein, its relatively small size of $44 \mathrm{kDa}$, its solubility in cultivation media, the absence of its posttranslational modifications, made this expression system an appropriate choice. Pančík et al. (2013) optimized both cultivation and induction conditions as well as purification procedure based on affinity chromatography for the proper production of soluble M3 protein. Expression of M3 protein in strain E. coli Rosetta (DE3) was effective, inexpensive, fast, and suitable for the continuation of the study of this protein.

In this study, we examined how a codon-changing mutation and deletion of the signal sequence of M3 protein change the chemokine-binding properties of this protein. This would contribute to a greater understanding of M3 protein biology and prospect to utilize its unique properties in gene therapy. We used conditions described by Pančík et al. (2013) for the production of recombinant M3 proteins in E. coli strain Rosetta (DE3), but we exploited the cells of $E$. coli strain - Rosetta-gami 2 (DE3) having non-reducing cytoplasm, which might enhance the formation of intramolecular disulphide bonds in recombinant M3 proteins produced. To prepare the full length M3 proteins of MHV-68 or MHV72 in these cells, we used expression plasmids prepared in the previous study. We then constructed a novel expression plasmid containing MHV-68 M3 gene sequence lacking the codons for the first 24 aa of the protein to study the role of the signal sequence of M3 protein in binding activity to chemokines. We successfully purified three recombinant M3 
proteins, two from MHV-68 and one from MHV-72, detectable by chemiluminescent dye using an antibody conjugate against the poly-histidine anchor of recombinant protein. As we expected, we obtained recombinant M3 proteins in amounts comparable with those produced before in Rosetta (DE3) cells. Similarly, the amount of purified proteins was independent on the localization of the His-tag anchor at the $\mathrm{C}$ - or N-terminal end of protein.

We have found that all recombinant M3 proteins prepared are able to bind each of chemokines tested but their binding activities against individual chemokine differed. The best binding we identified was of full length MHV-68 M3 protein to CCL5, when as few as only 2 ng of protein bound this chemokine. On the other hand, MHV-68 M3 protein truncated in the signal sequence had more than twenty times lower binding activity to CCL5, though 40 ng of protein still exhibited the binding. These results suggested a very important role of signal sequence of M3 protein in binding to CCL5. It is interesting that the same amount of the full length MHV-72 M3 protein (with a mutation at aa 307) displayed similar binding activity to CCL5 when compared to truncated MHV-68 M3 protein (95.6 vs $88.3 \%$ ). The truncation of MHV-68 M3 protein caused about five times reduced affinity to CXCL8 as compared to its full length counterpart. However, binding of truncated MHV-68 M3 protein to CXCL8 was close (by a quarter lower) to that detected for full length MHV-72 M3 protein (64.8 vs $90.0 \%)$. Similarly, truncated MHV-68 M3 protein exhibited reduced binding to CCL3 (about three times) in comparison to the full length MHV-68 M3 protein (24.3 vs $87.6 \%$ ), when both proteins displayed this binding only in undiluted form. Binding of MHV-72 M3 protein to CCL3 was two times weaker than that of truncated MHV-68 M3 protein (24.3 vs $12.3 \%$ ).

Results of this study indicated differences among three recombinant M3 proteins in the binding affinity to each of three chemokines tested. We have found that the binding of the full length MHV-68 M3 protein to CCL5 is about hundred times stronger than to CCL3 and about ten times stronger than to CXCL8. Also, both "modified" proteins (without signal sequence or with a single mutation at aa 307) exhibited binding stronger by order to CCL 5 than to CXCL8 and CCL3. All recombinant M3 proteins had the weakest binding to CCL3, when as much as $200 \mathrm{ng}$ of protein was necessary to detect the binding. The latter observation was first described in a study on M3 protein released to the media by virus-infected BHK-21 cells (Belvončíková et al., 2008). It should be mentioned that binding affinities of truncated MHV-68 M3 protein with His-tag anchor on its C-terminal end to CCL5, CXCL8, and CCL3 were comparable with those of truncated MHV-68 M3 protein with His-tag anchor on its N-terminal end studied by Pančík (2013). Thus, the localization of His-tag anchor in recombinant M3 protein had no effect on its binding to chemokines tested in this study (Matúšková, personal communication).

To sum up, the binding to CCL5 and CXCL8 seems to be related to signal sequence, which is not generally recognized to play a role in protein folding important for its biological activity. We found that the mutation present in MHV-72 M3 protein reduces binding to all chemokine tested, CCL5, CXCL8, CCL3, when its impact on the binding to CCL3 seems to be the most important. Both, the lack of signal sequence and the mutation (unique for MHV-72) cause the largest reduction of M3 binding to CCL3.

Our study brought new and unique data on biological properties of M3 protein-vCKBP of murine gammaherpesvirus, opening up the possibility of directly affecting some of its binding activities to a broad spectrum of chemokines. This work is the ground for our subsequent experiments on the site-directed mutagenesis of M3 protein aiming to obtain a protein with modified chemokine-binding activity to a individual chemokine. Modulation of chemokine activity is emerging as a potential therapeutic strategy for regulating the immune response. The virus-encoded CKBPs with different binding specificity offer as a unique source of chemokine inhibitors. Exploration of optimized chemokine inhibitors of viruses, which interacted with the chemokine system for millions of years, might help to control an overreactive inflammatory response in a number of human inflammatory diseases.

Acknowledgements. This work was supported by the grants from the Scientific Grant Agency of Slovak Republic VEGA No. 2/0091/13 and Slovak Research and Development Agency No APVV-0621-12.

\section{References}

Alcami A (2003): Viral mimicry of cytokines, chemokines and their receptors. Nat. Rev. Immunol. 3, 36-50. http://dx.doi. org $/ 10.1038 /$ nri980

Alexander JM, Nelson CA, van Berkel V, Lau EK, Studts JM, Brett TJ, Speck SH, Handel TM, Virgin HW, Fremont DH (2002): Structural basis of chemokine sequestration by a herpesvirus decoy receptor. Cell 111, 343-356. http:// dx.doi.org/10.1016/S0092-8674(02)01007-3

Belvončíková $\mathrm{P}$, Králová $\mathrm{A}$, Kúdelová $\mathrm{M}$, Hajnická $\mathrm{V}$, Režuchová I, Vančová I (2008): Chemokine-binding activities of M3 protein encoded by Murine gammaherpesvirus 72. Acta Virol. 52, 91-97.

Blaškovič D, Stančeková M, Svobodová J, Mistríková J (1980): Isolation of five strains of herpesviruses from two species of free living small rodents. Acta Virol. 24, 468.

Blaškovičová J, Tomášková J, Šupoliková M, Mistríková J, Kopáček J (2007): Sequence analysis of the regions flanking terminal repeats of Šumava islolate of murine gammaherpesvirus. Acta Virol. 51, 143-148. 
Bridgeman A, Stevenson PG, Simas JP, Efstathiou S (2001): A secreted chemokine binding protein encoded by murine gammaherpesvirus-68 is necessary for establishment of a normal latent load. J. Exp. Med. 194, 301-312. http:// dx.doi.org/10.1084/jem.194.3.301

Carfi A, Smith CA, Smolak PJ, McGrew J, Wiley DC (1999): Structure of a soluble secreted chemokine inhibitor vCCI (p35) from cowpox virus. Proc. Natl. Acad. Sci. USA 96, 1237912383. http://dx.doi.org/10.1073/pnas.96.22.12379

Ebrahimi B, Dutia BM, Roberts KL, Garcia-Ramirez JJ, Dickinson P, Stewart JP, Ghazal P, Roy DJ, Nash AA (2003): Transcriptome profile of murine gammaherpesvirus-68 lytic infection. J. Gen. Virol. 84, 99-109. http://dx.doi. org/10.1099/vir.0.18639-0

Fla-o E, Husain SM, Sample JT, Woodland DL, Blackman MA (2000): Latent murine gamma-herpesvirus infection is established in activated B cells, dendritic cells, and macrophages. J. Immunol. 165, 1074-1081. http://dx.doi. org/10.4049/jimmunol.165.2.1074

Halásová Z, Valovičová M, Mačáková K, Pančík P, Belvončíková $\mathrm{P}$, Režuchová I, Kúdelová M (2011): Partial genome (gp150): difference in the sequence between 72 and 68 strains. Virus Genes 26, 89-95.

Hughes DJ, Kipar A, Sample JT, Stewart JP (2010): Pathogenesis of a model gammaherpesvirus in a natural host. J. Virol. 84, 3949-3961. http://dx.doi.org/10.1128/JVI.02085-09

Hughes DJ, Kipar A, Leeming GH, Bennett E, Howarth D, Cummerson JA, Papuola-Pereira R, Flanagan BF, Sample JT, Stewart JP (2011): Chemokine binding protein M3 of Murine gammaherpesvirus 68 modulates the host response to infection in a natural host. PLoS Pathog. 7, e1001321. http://dx.doi.org/10.1371/journal.ppat.1001321

Jensen KK, Chen SC, Hipkin RW, Wiekowski MT, Schwarz MA, Chou CC, Simas JP, Alcami A, Lira SA (2003): Disruption of CCL21-induced chemotaxis in vitro and in vivo by M3, a chemokine-binding protein encoded by murine gammaherpesvirus 68. J. Virol. 77, 624-630. http://dx.doi. org/10.1128/JVI.77.1.624-630.2003

Kožuch O, Reichel M, Leššo J, Remeňová A, Labuda M, Lysý J, Mistríková J (1993): Further isolation of murine herpesvirus from small mammals in southwestern Slovakia. Acta Virol. 37(1), 101-105.

Kúdelová M, Rajčáni J (2009): Gammaherpesviruses and oncogenesis. In Tao HE (Ed): DNA Tumor Viruses. Nova Science Publishers Inc., New York, pp. 193-231.

Kúdelová $\mathrm{M}$, Halásová $\mathrm{Z}$, Belvončíková $\mathrm{P}$, Pančík $\mathrm{P}$, Režuchová $\mathrm{I}$, Valovičová M (2012): Partial genome analysis of murine gammaherpesvirus 4556. Acta Virol. 56, 177-186. http:// dx.doi.org/10.4149/av $2012 \quad 03 \quad 177$

Laemmli UK (1970): Cleavage of structural proteins during the assembly of the head of bacteriophage T4. Nature 227, 680-685. http://dx.doi.org/10.1038/227680a0

Lalani AS, Barrett JW, McFadden G (2000): Modulating chemokines: more lessons from viruses. Immunol. Today 21, 100-106. http://dx.doi.org/10.1016/S0167-5699(99)01556-X

Lira SA, Viejo-Borbolla A, Shang L, Martin AP (2009): The chemokine-binding protein $\mathrm{M} 3$ as a tool to understand the chem- okine network in vivo. Methods Enzymol. 460, 193-207. http://dx.doi.org/10.1016/S0076-6879(09)05209-4

Luster AD (2002): The role of chemokines in linking innate and adaptive immunity. Curr. Opin. Immunol. 14, 129-135. http://dx.doi.org/10.1016/S0952-7915(01)00308-9

Mačáková K, Matis J, Režuchová I, Kúdela $\mathrm{O}$, Rašlová $\mathrm{H}$, Kúdelová M (2003): Murine gammaherpesvirus (MHV) M7 gene encoding glycoprotein 150 (gp150): difference in the sequence between 72 and 68 strains. Virus Genes 26, 89-95. http://dx.doi.org/10.1023/A:1022390407991

Marques S, Efstathiou S, Smith KG, Haury M, Simas JP (2003): Selective gene expression of latent murine gammaherpesvirus 68 in B lymphocytes. J. Virol. 77, 7308-7318. http:// dx.doi.org/10.1128/JVI.77.13.7308-7318.2003

Martin AP, Alexander-Brett JM, Canasto-Chibuque C, Garin A, Bromberg JS, Fremont DH, Lira SA (2007): The chemokine binding protein $\mathrm{M} 3$ prevents diabetes induced by multiple low doses of streptozotocin. J. Immunol. 178, 4623-4631. http://dx.doi.org/10.4049/jimmunol.178.7.4623

Martin AP, Grisotto MG, Canasto-Chibuque C, Kunkel SL, Bromberg JS, Furtado GC, Lira SA (2008): Islet expression of M3 uncovers a key role for chemokines in the development and recruitment of diabetogenic cells in NOD mice. Diabetes 57, 387-394. http://dx.doi.org/10.2337/ $\underline{\mathrm{db} 07-1309}$

Mistríková J, Rašlová H, Mrmusová M, Kúdelová M (2000): A murine gammaherpesvirus. Acta Virol. 44, 211-226.

Nash AA, Dutia BM, Stewart JP, Davison AJ (2001): Natural history of murine gamma-herpesvirus infection. Philos. Trans. R. Soc. Lond. B. Biol. Sci. 356, 569-579. http://dx.doi. org/10.1098/rstb.2000.0779

Pančík P, Bauerová V, Kúdelová M (2013): Purification of recombinant M3 proteins of murine gammaherpesviruses 68 and 72 expressed in Escherichia coli. Acta virol, 57 (1), 59-68. http://dx.doi.org/10.4149/av $201301 \quad 59$

Parry CM, Simas JP, Smith VP, Stewart CA, Minson AC, Efstathiou S, Alcami A (2000): A broad spectrum secreted chemokine binding protein encoded by a herpesvirus. J. Exp. Med. 191, 573-578. http://dx.doi.org/10.1084/jem.191.3.573

Proudfoot AE, Handel TM, Johnson Z, Lau EK, LiWang P, ClarkLewis I, Borlat F, Wells TN, Kosco-Vilbois MH (2003): Glycosaminoglycan binding and oligomerization are essential for the in vivo activity of certain chemokines. Proc. Natl. Acad. Sci. USA 100, 1885-1890. http://dx.doi. org/10.1073/pnas.0334864100

Pyo R, Jensen KK, Wiekowski MT, Manfra D, Alcami A, Taubman MB, Lira SA (2004): Inhibition of intimal hyperplasia in transgenic mice conditionally expressing the chemokinebinding protein M3. Am. J. Pathol. 164, 2289-2297. http://dx.doi.org/10.1016/S0002-9440(10)63785-6

Rajčáni J, Kúdelová M (2007): Murid herpesvirus 4 (MHV 4): an animal model for human gammaherpesvirus research. In Minarovits J, Gonczol E, Valyi-Nagy T (Eds): Latency Strategies of Herpesviruses. Springer Berlin Heidelberg, New York, pp. 102-136. http://dx.doi.org/10.1007/9780-387-34127-9 5

Rašlová H, Matis J, Režuchová I, Mačáková K, Berebbi M, Kúdelová M (2000): The bystander effect mediated by the new 
murine gammaherpesvirus 72-thymidine kinase/ 5'fluoro-2'-deoxyuridine (MHV72-TK/5-FUdR) system in vitro. Antivir. Chem. Chemother. 11, 273-282. http:// dx.doi.org/10.1177/095632020001100403

Rašlová H, Berebbi M, Rajčáni J, Sarasin A, Matis J, Kúdelová M (2001): Susceptibility of mouse mammary glands to murine gammaherpesvirus 72 (MHV-72) infection: evidence of MHV-72 transmission via breast milk. Microb. Pathog. 31, 47-58. http://dx.doi.org/10.1006/ mpat.2001.0441

Sarawar SR, Lee BJ, Anderson M, Teng YC, Zuberi R, Von Gesjen $S$ (2002): Chemokine induction and leukocyte trafficking to the lungs during murine gammaherpesvirus 68 (MHV-68) infection. Virology 293, 54-62. http://dx.doi. org/10.1006/viro.2001.1221

Simas JP, Swann D, Bowden R, Efstathiou S (1999): Analysis of murine gammaherpesvirus- 68 transcription during lytic and latent infection. J. Gen. Virol. 80, 75-82. http://dx.doi. org/10.1099/0022-1317-80-1-75

Speck SH, Ganem D (2010): Viral latency and its regulation: lessons from the $\gamma$-herpesviruses. Cell Host Microbe 8,100-15. http://dx.doi.org/10.1016/j.chom.2010.06.014

Sunil-Chandra NP, Efstathiou S, Arno J, Nash AA (1992): Virologi$\mathrm{cal}$ and pathological features of mice infected with murine gamma-herpesvirus 68. J. Gen. Virol. 73, 2347-2356. http://dx.doi.org/10.1099/0022-1317-73-9-2347

Valovičová M, Režuchová I, Mačáková K, Petrová P, Matis J, Kúdelová M (2006): Murine gammaherpesvirus (MHV) MK3 gene sequence diversity among 72, 4556, and 68 strains. Virus Genes 33, 51-58. http://dx.doi.org/10.1007/ $\underline{\text { s11262-005-0038-4 }}$

van Berkel V, Preiter K, Virgin HW 4th, Speck SH (1999): Identification and initial characterization of the murine gammaherpesvirus 68 gene M3, encoding an abundantly secreted protein. J. Virol. 73, 4524-4529. van Berkel V, Barrett J, Tiffany HL, Fremont DH, Murphy PM, McFadden G, Speck SH, Virgin HW 4th (2000): Identification of a gammaherpesvirus selective chemokine binding protein that inhibits chemokine action. J. Virol. 74, 6741-6747. http://dx.doi.org/10.1128/JVI.74.15.6741-6747.2000

van Berkel V, Levine B, Kapadia SB, Goldman JE, Speck SH, Virgin HW 4th (2002): Critical role for a high-affinity chemokine-binding protein in gammaherpesvirus-induced lethal meningitis. J. Clin. Invest. 109, 905-914. http://dx.doi. org/10.1172/JCI14358

van Regenmortel MHV, Fauquet CM, Bishop DHL (2000): Herpesvirus family. In Virus Taxonomy: Classification and Nomenclature of Viruses. 7th ICTV Report, Academic Press, San Diego, pp. 220-226.

Virgin HW 4th, Latreille P, Wamsley P, Hallsworth K, Weck KE, Dal Canto AJ, Speck SH (1997): Complete sequence and genomic analysis of murine gammaherpesvirus 68. J. Virol. 71, 5894-5904.

Wágnerová M, Chalupková A, Hrabovská Z, Ančicová L, Mistríková J (2015): Possible role of different animal species in maintenance and spread of murine gammaherpesvirus 68 in the nature Acta Virol. 59, 14-19. http://dx.doi. org/10.4149/av 2015 $01 \quad 14$

Webb LM, Clark-Lewis I, Alcami A (2003): The gammaherpesvirus chemokine binding protein binds to the $\mathrm{N}$ terminus of CXCL8. J. Virol. 77, 8588-8592. http://dx.doi.org/10.1128/ JVI.77.15.8588-8592.2003

Wu L, Huang TG, Meseck M, Altomonte J, Ebert O, Shinozaki K, García-Sastre A, Fallon J, Mandeli J, Woo SL (2008): rVSV(M Delta 51)-M3 is an effective and safe oncolytic virus for cancer therapy. Hum. Gene Ther. 19, 635-647. http://dx.doi.org/10.1089/hum.2007.163

Zlotnik A, Yoshie O (2000): Chemokines: a new classification system and their role in immunity. Immunity $12,121-127$. http://dx.doi.org/10.1016/S1074-7613(00)80165-X 